\title{
It's a hard knock life the survival strategies of Dutch Mulas in Peruvian prisons
}

\author{
Elga Sikkens $^{2} \cdot$ Marion van $\operatorname{San}^{1}$
}

Published online: 21 May 2015

(C) The Author(s) 2015. This article is published with open access at Springerlink.com

\begin{abstract}
Not much research has been done in the Netherlands on the ways in which Dutch women experience and survive a prison sentence abroad. The research underlying the present article focused on Dutch female prisoners in foreign countries, using an ethnographic research method. The article looks at the prison experiences of Dutch mulas in Peru and their strategies of survival. The ways in which these women react to their detention can be traced back to existing literature on the importation theory and the deprivation theory. The article also examines the various coping strategies that are used to survive a prison sentence abroad. These strategies appear to be related both to the life experiences of the women (importation theory) and the experienced prison environment (deprivation theory).
\end{abstract}

\section{Introduction}

A relatively large amount of research has been conducted on the prison experiences of women [1-10], but as far as we know, very little field research has been done by researchers on the experiences of women incarcerated in a foreign country. The research on which this article is based deals with Dutch women detained in prisons in Peru. This ever-growing group of detainees is faced with surviving a prison sentence far from home. Although no exact figures are available, the involvement of women in drug smuggling worldwide has reportedly increased over the past several years [11,12]. In 2005, there were thirteen Dutch women in Peruvian prisons; in 2010, the period of our research, there were twenty-five [13,14]. In April 2012, the number had fallen to eleven as a result of sentence reductions of up to 9 years.

Marion van San

vansan@risbo.eur.nl

1 Rotterdam Institute for Social Policy Research, Erasmus University Rotterdam, Rotterdam, Netherlands

2 Faculty of Social and Behavioral Sciences, Utrecht University, Utrecht, Netherlands 
Prison life in Peru is very different from life in a Dutch prison and Dutch inmates in Peru are faced with all sorts of problems that are usually non-existent in their own country. For instance, there is often a language barrier, most Dutch prisoners receive no visits from relatives, some prison officials may be corrupt, and standards of hygiene and privacy are often lower than in The Netherlands (Ministerie [15]). In short, the conditions in foreign prisons are likely to be tougher than those in prisons in The Netherlands. The present article aims to examine how Dutch women faced with such circumstances manage to endure their incarceration. This study was part of a larger research project on Dutch women incarcerated abroad.

\section{Survival in theory}

With the exception of Janine Janssen [16], who studied South-American mulas $^{1}$ in the Bijlmer prison in Amsterdam, ethnographic methods are almost never used in prison research in the Netherlands and, as far as we were able to ascertain, this type of research has never been conducted on Dutch citizens incarcerated abroad. This is all the more remarkable given that ethnographic research can provide a rich insight into prison life. Janssen's research is particularly interesting. Over the course of several months, she spent many hours with nine Latin American women who were detained in a Dutch prison after being caught smuggling cocaine at Schiphol Airport. Using participant observation and in-depth interviews, Janssen was able to show that both the importation and the deprivation theory were applicable to the prison experience of Latinas in the Netherlands. The importation theory holds that the manner in which people cope mentally with detention is determined by their way of life prior to their imprisonment $[10,17]$. Supposedly, detainees are more often victims of painful life experiences, such as physical and/or sexual abuse, than people without a criminal record [18-21]. Green et al. [20] for example state that "there is an increasing understanding of the fact that many women in prison or jail for committing crimes are crime victims themselves. In particular, they have often been abused sexually and physically in childhood, many have been raped, and exposure to family violence is endemic." According to Adams [22] people develop ways of dealing with painful experiences and they take these strategies with them into the prison system. Variables such as a criminal record, cultural background and mental health, as well as personal characteristics such as ethnic origin, gender and age, are also imported into the prison and these factors will determine to a certain extent how an inmate deals with his or her sentence [7,22-24]. However, a prisoner's personal characteristics and life history are not enough to explain a person's response to imprisonment because, as argued by Zamble \& Porporino [24], human behaviour is rarely determined by personal characteristics alone. It is much more often the result of interactions between an individual and his or her circumstances. In line with this argument, prison conditions are also considered important in determining how an individual responds to his or her imprisonment. The deprivation theory holds that a person's response to a prison term will be determined by the challenges imposed by the prison system and by circumstances over which the prisoner has no control $[10,23]$. In Gresham Sykes' groundbreaking study 'The Society of Captives' (1958), these

\footnotetext{
${ }^{1}$ Mulas is Spanish for drug mules: people that are paid to smuggle drugs through country borders.
} 
challenges are referred to as the pains of imprisonment. Restrictions to the freedom of movement lead to social deprivation: for instance, the prisoner is no longer able to maintain social ties with family and friends. He is also limited in his freedom to receive goods and services and is deprived of heterosexual relationships. Sykes also mentions the loss of autonomy and the loss of security as consequences of a prison sentence.

In common with many other researchers, we believe that the importation theory and the deprivation theory are complementary in explaining the prison experience. Our research, however, focuses not only on the prison experiences of women, but also on the ways in which these women 'survive' their sentence. Given the fact that most women survive their detention and come out of prison alive, the term 'survival' should not be taken literally, but this is not to say that the female prisoners we interviewed all came away 'undamaged': many women in detention reportedly suffer from depression, posttraumatic stress disorder and other psychological complaints [6,25,26]. In the following, the term 'survival' is used to mean 'staying sane'.

Previous studies on women's prison experiences [3-6,10] have demonstrated that control over privacy is a necessary condition for women to endure a prison sentence. When female detainees are unable to establish a sufficient level of privacy within their immediate environment, such as their own cell, this may lead to self-destructive behaviour [10], although there is also some evidence that too much privacy leads to self-harm and suicide ideation (see [5,27]). Besides concerns about privacy, a meaningful daily routine can also help to make a prison sentence more bearable and improve social relations within the prison. When women are imprisoned, their main concern is about their lack of contact with family members and friends and the fact that they are no longer able to take care of their families [4]. Women seem to survive a prison sentence by constructing a life within the prison walls where privacy and safety are guaranteed. A relatively interesting daily schedule and a reasonable level of comfort are also important, but crucial to the survival of women in prison appear to be their relationships with fellow detainees, to the extent that they provide a sense of security and help prevent destructive behaviour [7,10]. This brings us to what Lazarus calls coping strategies. Coping has to do with the ways in which an individual handles stress and stress-inducing situations [28,29]. When a situation is appraised as threatening (primary appraisal), people evaluate their resources and options for responding to this situation (secondary appraisal) and search for appropriate coping strategies [24]. Examples of such coping strategies are: making plans to change stressful situations, accepting responsibility, denial or distancing, daydreaming, seeking support and comfort from others, positive thinking by emphasizing personal growth, social isolation or withdrawal in grief, stress reduction through drinking, smoking, drug use, playing sports, or through humour. Every person will use different strategies to deal with difficult situations and/or employ multiple strategies simultaneously [30].

As mentioned earlier, the manner in which prisoners deal with their sentence is determined by their particular life experiences as well as by the nature of the circumstances of their detention. Their choice of a particular coping strategy is likewise determined by importation and deprivation variables [24]. There appears to be a striking continuity between the coping strategies used by prisoners in their life prior to their detention and the coping strategies they resort to in prison [22]. Two prisoners can react totally differently to a lack of family contact. Whereas one prisoner, as a result of his or her character traits and experience of life, may seek out new social contacts 
within the prison walls, another may withdraw and fall into depression and apathy. Both are ways of coping, and both are determined by personal characteristics as well as by the specific deprivations imposed by the prison setting. The manner in which women survive a prison sentence is possibly partly dependent on the coping strategies they employ and the choice of a particular coping strategy is most likely influenced by prior life experiences as well as by prison conditions.

\section{Common ways of coping}

A common strategy for prisoners to cope with their imprisonment is a religious conversion [25]. Clear et al. [25] found that conversion to religion and the manner in which converted prisoners express their newfound religious beliefs, is dependent on the deprivation experienced in prison as well as on imported social values. According to Johnson \& Larson [31], religion helps detainees to deal with both social and emotional deprivation. Religion does nothing to alter the fact that imprisoned women have been isolated from their families and are forced to survive in a prison environment (cf. Kerley \& Copes, 2009), but it can help them to handle these circumstances by improving their coping skills and by giving them peace of mind, hope, and a sense of dignity they never knew before [31,32].

Another coping strategy allegedly characteristic of women in detention is forming a surrogate family or entering into a lesbian relationship as a response to prison circumstances and the lack of contact with family and friends $[8,10]$. Women in prison are assumed to form surrogate families and lesbian relationships in order to get a sense of belonging, to ensure support, and to secure protection against potential dangers. In male prisons, this is most commonly achieved by joining a gang [4,10,33].

Finally, most women in prison have met with adversities during their lives and suffer from the lack of contact with partners, children, and other family members during their imprisonment (see [34]). 'Not thinking' is a common coping strategy used in response to this type of deprivation. Banishing all thoughts of life outside prison is often used to endure the incarceration. Berger [35] argues that a prison sentence constitutes a 'massive attack' on a person's identity; Schmid and Jones [36] describe how prisoners respond to this attack by making a distinction between their 'real' identity (the identity they had before they were imprisoned) and a 'false' identity created in prison. Detainees soon find out that they cannot be themselves in prison because it would make them vulnerable. They 'suspend' their real identity during the time of their imprisonment. When women in prison mention that they 'try not to think', this is assumed to reflect the deferment of their pre-prison identity. For the time being, they suspend who they are because they are afraid of being overwhelmed by emotions, something that would leave them exposed inside an institution such as a prison. It is possible that some women were already familiar with this coping strategy prior to their incarceration, as a means to cope with earlier life distress.

This article focuses on the question of how Dutch women imprisoned for drug smuggling in Peru experience and survive their detention, and will focus on the perception of Dutch women incarcerated in Peru on their prison experience and coping strategies. We track the lives of these women before their detention in light of the importation theory, because the response to a prison sentence and the choice of a particular survival strategy are possibly determined by prior life experiences. We also 
examine the conditions and hardships the women face in prison, as well as their ways of coping with these conditions. We will try to show how the coping strategies they use are possibly connected to their life experiences and to prison life in Peru. The results could perhaps be generalized to women from different origins, though it would depend on the similarity of the country they came from. Janssen [16] showed in her research that women from different countries, experience their time in prison in The Netherlands in different ways, due to culture and other importation variables. Furthermore, it should be noted that due to the small sample size, it may be difficult to draw conclusions that are generalizable to the larger population.

\section{Method}

Ethnographic research methods can yield rich and vivid descriptions of people in their everyday surroundings, especially when the researcher is prepared to put up with a certain amount of discomfort [37-39]. This is not to say that researchers should identify with their informants, but rather that they must be willing to participate as much as possible in the world of their research subjects, even though this is not always feasible in prison research $[38,39]$. In our research, we have tried to give as detailed a picture as possible of Peruvian prisons and the experiences of their Dutch inmates with the aim of contributing to the development of theories on coping in detention. By describing both prison life and our research experiences as realistically as possible, we hope to add to the existing body of knowledge in this field. It should be noted that ethnography involves more than just telling 'interesting stories'. The rich descriptions and analyses derived from this method constitute an important tool for answering research questions and thereby contribute to the further development of more general theories [38,39]. On a more practical level the ethnographic method helped us to gain the trust of our informants. When we first visited the prison, most women were reluctant to talk to us about their lives because they found it too painful to revisit the past, but they soon got used to our recurring presence and this allowed us to gradually gain the inmates' trust.

\section{The field}

Peru has 66 prisons, run by the National Penitentiary Institute (INPE) and the National Police of Peru (PNP). In 201253.203 people were held in these prisons, of whom 3241 were women. Overpopulation existed as the prisons were built to keep 28.508 persons only [1]. According to Peruvian government statistics from 2012, the penal Santa Monica housed 1285 women, while it was only designed to accommodate 738 inmates [40]. It goes without saying that such overcrowding has a major impact on the life of all prisoners.

In $89 \%$ of the facilities, water and electricity were in fair or poor condition. Medical treatment services were said to be fair or poor in $71 \%$ of the facilities [41]. 32 of the prisons for women, concern mixed gender prisons. The mixed prison in Huaraz where we conducted our research, for example, accommodated 42 women opposed to 548 men. As these prison facilities were originally built for men only, women often cannot use the services available for men, because they are held in a separate wing. This affects their conditions of detention (Ministerio de Justicia \& [42]). 


\section{Access to the field}

We began our research at the foreign desk of the Dutch Probation Service (Bureau Buitenland van Reclassering Nederland), where we examined 325 files containing information on women incarcerated abroad. These files consist of a form, filled out by the detained women, about their background. Also reports on how the women are doing, written by a volunteer who visits the girls every month, are part of the file. Beforehand, we had established a set of criteria to identify relevant cases. The first criterion concerned country of birth: the women had to have been born in the Netherlands because the larger research project of which this article forms part also looked at the drug networks of Dutch women. The idea was that these networks would be different for women born in the Netherlands than for Dutch passport holders from the Netherlands Antilles. The second criterion was that the women had personally smuggled cocaine, as the larger project was originally designed to examine the motives of cocaine smugglers. On the basis of these criteria we compiled a list of all Dutch female cocaine smugglers detained abroad. We then selected the countries where eight or more Dutch women were being detained and read the files of women suspected of smuggling cocaine who were born in the Netherlands. In the end, Peru emerged as the most suitable place to conduct our research because it had the highest number of women detainees who met our criteria (i.e., fourteen in total). All women detained in Peru at time of research, were charged with drug smuggling. All of them left their homes for a 'short holiday break', not thinking about a possible confinement abroad. What remains, are children who need to be accommodated, houses that can no longer be kept, jobs or education that come to a hold, and family who suddenly has to take care of a family member who is imprisoned abroad (Ministerie [15]).

Access to the prisoners was facilitated by the foreign desk of the Probation Service. Its officers maintain close contact with the Dutch embassy in Peru, which is able to arrange visits to local prisons. Their assistance made it relatively easy to gain entrance to the two Peruvian prisons where Dutch women were detained: the Penal Santa Monica in Lima and the Penal Huaraz in the mountain town of Huaraz. We also visited and interviewed a number of women who had already been released on probation ('semi-libertad'). In Peru, prisoners who demonstrate good behaviour are released after serving two-thirds of their sentence, on condition that they remain in the country. We were able to find some of these women because one of them had become friends with a female guard at the gate of Santa Monica. She became our 'gatekeeper' and helped us get in touch with other Dutch ex-detainees.

\section{Data collection}

The research data were collected in April and May of 2010. At the time, there was still no treaty between the Netherlands and Peru allowing the transfer of prisoners. ${ }^{2}$ This meant that Dutch nationals arrested and convicted in Peru had to serve out their entire sentence in a Peruvian prison. Several of the fourteen women on our list were not willing to participate in the research. It is unknown why, as the other respondents

\footnotetext{
${ }^{2}$ On May 12, 2011, the Netherlands and Peru signed an extradition treaty. See: http://www.rijksoverheid.nl/ nieuws/2011/05/12/nederland-en-peru-sluiten-wots-verdrag.html
} 
simply told us that these women did not want to meet us. Unfortunately we could not verify this, as the women unwilling to participate, stayed in their cells. The researchers were not allowed to enter the cell blocks, and depended on the women who were curious about our visit, and were eager to come and talk to us. We were also unable to track down all of the women who had been released on probation.

In the end, we were able to interview and spend time with ten Dutch women convicted of smuggling cocaine, both in and outside the prisons. Five of them were still in detention, while the other five were living outside the prison walls. Although our research was primarily focused on prison experiences, we also interviewed the women in semi-libertad, as they had been released from prison in the last year and were still under the obligation to report regularly to the prison authorities. We asked the women on probation about their time in prison in retrospect; one would expect that these women look back differently on their experiences in prison once they are released. However, in this study there were no differences found between the women who had semi-libertad and the women who were still incarcerated, perhaps because the women on probation were still "doing time" outside the prison walls.

The average age of the women we interviewed was 35 . The youngest was 18 when she was arrested, the oldest 54. Five of the women were mothers. Half of them had previously been addicted to alcohol or drugs, and half had had prior police contact in the Netherlands, ranging from fines to serious criminal records. All of the women had a low level of vocational or secondary education and most of them had accumulated sizable debts. Two informants had served time in foreign prison before.

We conducted in-depth interviews because an open-ended method of data collection seemed best suited to answer our research questions. Guided by a list of topics, we asked the women about their life stories. These topics included (but are not confined to) educational and working careers, social contacts, criminal histories and prison experiences. Each respondent gave us her verbal consent to participate in the research.

An additional advantage of conducting interviews was our physical presence in the field. This enabled us to observe prison life firsthand and experience for ourselves the conditions our respondents were faced with on a daily basis. For example, one of the prison guards offered us the opportunity to jump the queue at the prison gate for the equivalent of EUR 2,50. We were also able to experience what it meant to have to share a small space with an ever-growing population of inmates. The interviews in prison were mostly conducted on visiting days, which meant trying to have a conversation in an overcrowded prison courtyard.

We met most of our respondents two times. The first meeting was meant to introduce ourselves and to plan an interview. The second meeting lasted in general $1.5 \mathrm{~h}$, in which the interview was conducted. We met three of the women who were on probation again after the interview, either to go for a coffee, to exchange books, or just to break the daily routine of their lives outside of prison.

All interviews conducted outside the prison were recorded with the help of a voice recorder and later transcribed verbatim. Unfortunately, we were not able to bring recording equipment into the prisons. Despite our many requests to the guards, to the female warden of the women's prison of Santa Monica, and even to the president of all Peruvian prisons, we never received permission to record our conversations with prisoners. In a bar across the street someone offered to smuggle a recorder into the prison through a corrupt prison guard, but we declined the offer so as not to endanger 
the project. Instead, we wrote down the women's responses as fully as possible and transcribed our notes immediately after the interviews to retain maximum information. We used pseudonyms to ensure the anonymity of the participants in this study.

\section{Data analysis}

For analysis, the interview transcripts were coded by two researchers. By reading the interviews and labeling any fragment, sentence or paragraph within an interview that seemed to represent topics that were of interest, a first analysis was done. The researchers compared their codes to obtain researcher triangulation. Unfortunately no inter-rater reliability was measured, which could be a potential pitfall of this study.

What helped the researchers focus, were the research questions and topic lists that were based on literature about characteristics of mulas [16,43], coping [30], and prison experiences $[4,44]$. During the interviews the researchers asked about these themes and topics, for example about their lives before the imprisonment and about their lives within the prison walls; these themes and topics could be labeled as such during the coding. After coding the interviews, all labels on the same topic were put together in one document, so similarities and differences between interviews on a certain topic, could be easily found.

\section{Life experiences of Dutch mulas $^{3}$}

The Dutch women who are imprisoned in Peru, experienced a relatively large amount of adversities in their lives: violent relationships, addiction (personal or a family member), and mental health problems like depression and burnout were common. Most of them had problems when they were still in the Netherlands, and some could no longer work due to psychological reasons. It seems that these women smuggled drugs out of desperation. For example Louise, a 56-year-old woman, who had to stop working due to a burnout, and had been under the scrutiny of debt restructuring for 7 years before she was offered 5000 euros for smuggling drugs at a birthday party.

Nearly all the women we spoke to had left their parental home at a very young age; some of them moved to boarding schools, while others moved in with their boyfriends. Most left their parents' house due to problems at home or because of the (temporary) incapacity of the parent or parents to take care of them. For instance, Nicky left her home at a very early age; at fifteen she ran away and moved in with her older and violent boyfriend. She was led into a world of drugs, which her boyfriend was already acquainted with. From that moment on, she dealt drugs from her scooter, and refused to obey the law. It appears that she lived on the edge when she was still outside of prison, satisfied with earning money through drug dealing and her search for adventure. Moreover, it seems that Nicky did not conform to the rules in prison either. She withdrew from taller (manual work), and resorted to drug use. This seems to confirm that coping strategies are indeed influenced by former life experiences as Nicky again

\footnotetext{
${ }^{3}$ In the limited space of this article, it would not be feasible to reconstruct the complete life histories of these women. Instead, a couple of life experiences will be highlighted to demonstrate the correlation between the life course, and the coping strategies which follow.
} 
did not obey to any rules, though her coping in prison may not have been a rational choice but her only option to survive.

There are more examples of women who appear to use coping strategies determined by former life experiences. For instance, Karin, who seemed to be an aspiring and welleducated woman before her imprisonment. Behind prison walls she became the spokesperson of many fellow inmates, and helped them to fill out their forms. Not only did she do this to help those who were in need, Karin also assisted other women to make herself feel useful. This reinforced her self-esteem, which helped her to survive the difficult time in a Peruvian prison.

Eva was a quiet, but also depressed woman prior to her detention, who struggled to keep her head up during her detention. In prison she preferred to withdraw to her cell. The ways in which these women handle their detention abroad, and the coping strategies they adopt, mainly seem to be determined by their course of life.

\section{Deprivation in a Peruvian prison}

The circumstances in Peruvian prisons seem to be tougher than circumstances in detention facilities in their home country. According to the interviewees, corruption is for example an unfortunate part of daily life in the Santa Monica and Huaraz penitentiaries. Prison guards earn such a small amount of money that it makes it easy for prisoners to bribe them. But the guards would not keep the money. A major part of the corrupt income is said to be handed over to the local prison director, who in turn divides the money among the staff. Corruption, so it seems, is a means used by prison personnel to gain extra income.

Among the detainees there is not a lot of physical violence, and according to the women interviewed, the prison guards do not use any force on them either. The exclusively female guards are not allowed to touch prisoners and there are a remarkably small number of prison guards present within the prison compound. Approximately 12 female guards watch a group of roughly 1000 women. Delegadas, who are representatives of the detainees, keep order. These delegadas make the rules on a piso [ward] and are, for instance, responsible for the shared finances of cleaning goods. Due to a shortage of prison staff, the Peruvian prisons are actually run by prisoners. According to Peruvian law, this is prohibited: convicts are not allowed to be in a dominant position over other convicts. However, the shortage in personnel is solved this way. To prevent a breakout, the prison walls are guarded by heavily armed men.

Rules, set by the prison regime, seem to be arbitrary. One warder allows certain things while another forbids the same, and rules can change overnight. This causes a lot of frustration among the imprisoned women. We as researchers were also confronted with the arbitrary rules: 1 day a letter from the Dutch embassy was sufficient to enter the prison, but the next day we were denied entrance because the same letter was rejected.

Besides the difficulties named above, there are certain things that many of the Dutch women in Peruvian prisons find tough. Though the imprisoned Dutch women each experience their prison time in their own way, there are some common aspects, like the ones named above, that most of the women find hard. The mentality of their Peruvian fellow inmates is strange to them. Dutch women find them impudent and unhygienic 
and they are annoyed by their manner of talking, which is more like screaming. Also, the Dutch detainees we interviewed reported that they detest all the gossiping that would happen because of jealousy. Some women see the Peruvians as the initiators of gossip, others seem to think that Dutch women gossip as well. It is unclear though, whether the Dutch women had a sufficient knowledge of the Spanish language to perceive gossiping. As well as speaking badly about each other, the women reported that they do not have a lot of respect for one another's belongings. According to our informants, stealing among Peruvian women would occur regularly.

The women's prison in Lima is overcrowded, which makes it difficult to avoid people or to withdraw from the crowds. Also, hygiene is inadequate. It is very nasty in here, Shirley says, because you don't put your toilet paper in the toilet but in the basket next to it. 150 women, four toilets, no way I'm going to clean that. And sometimes there is no running water. The other day there was no water for two whole days! But I just pay 20 cents so I can use the toilet upstairs at the sickbay. But even upstairs there's no way they leave you be, banging on the door because they want to use the toilet too (Shirley, 38).

The lack of privacy is considered to be the toughest thing about their stay in Santa Monica prison. The cacophonic sounds, caused by the presence of thousands of women, make the mulas realize that they are never alone. Michelle proudly recalls memories of the curtains she had made to give her some privacy in her upper bunk bed. I had a curtain made around my bed, which I could close, 'ha, alone!' [laughs]. 'Cos when I slept in the salon [TV room] I wasn't allowed to have a curtain 'cos then no one could watch the TV. So yes, sometimes I would sit with someone who had a lower bed or had her bed in a cell, but you'd never have real privacy. Only after I got into that cell room, after a year, I had my curtain. You could just close your curtain and when someone comes in to see you, you say 'I'm not there!' (Michelle, 21).

As well as the penitentiaries in Lima being overcrowded, medical care within the facilities is said to be seriously lacking. Some of the women have seen fellow inmates die and feel that this was unnecessary. If you didn't have the money they would just leave you to die. Everything costs money. So if you don't have cash, you can't go to hospital. You know, people with AIDS in there died, only because they didn't get medical treatment. I've seen that a few times, people who died because of a lack of medication (Karin, 36).

The geographical distance between Peru and the Netherlands is large and it is hard on the women that because of the long and expensive journey they receive very few visitors. The long distance between them and their families is perceived to be very hard: for example, to know that family on the other side of the world are not doing well is seen as extremely tough. Also, the limited contact moments are difficult for them. Telephones can only be reached after a very long queue. When it is an inmate's turn to use the phone, usage is limited to 10 min only. Letters and postal packages are brought in once a month by the Dutch embassy or volunteers, and every Thursday, during Bible class, a maximum of three e-mails are allowed to be sent.

\section{Survival through persistence}

Documentaries that can be seen on television often show the excessive violence that exists in South American prisons. This is the same image that most Dutch women have 
when they enter a Peruvian prison: 'I was so scared (...) a nightmare that they would rape me, that they would beat me (...) you just don't know. The only thing you know is what you have seen on TV' (Agnes, 41).

But the women we spoke to compare Peruvian female prisons with boarding schools instead. The threatening image they had of South American prisons did not come true. On the other hand, the women did find life in these 'boarding schools' hard. 'But you have to go on' is what they frequently told us. How do these women survive their sentence in a foreign prison? What coping strategies do they use and do these strategies correspond to the strategies that were found in existing literature?

During our field study we found the following coping strategies: (conversion to) religion, bonding through play families, bonding through romantic relationships, join in activities, help fellow inmates, refrain from thinking, and put the own identity on hold. It seems that the coping strategies that are used by Dutch women to survive their detention in Peru, are determined by their experiences in life and by the prison context. For example, six out of ten Dutch women use their faith in God to stay strong. Religion is a coping strategy that is also named in existing literature. Two women were already religious when they were incarcerated (import), but the other four women got to know God while in prison (deprivation). Every Thursday afternoon Mary comes by. She is an American reverend's spouse who teaches Bible study. Most Dutch women participate in these classes. They explain that their faith in God helps them to keep going, even if they are in prison far away from their families.

We found that Dutch women that are imprisoned in Peru, cope with their imprisonment by mutually bonding with their fellow inmates and forming family ties. A fellow inmate then becomes a sister, a mother or a niece and with them they share their joys and sorrows. This can also be seen as a coping strategy: it is a response to prison circumstances and them missing their own family. The women imprisoned in Peru also use this coping strategy to survive: 'You kind of observe who you can trust and then you sort of start a relationship. If one didn't have money, the other one had. You took care of each other. Also emotionally: if you got bad news the other one was there to support you' (Karin, 36).

Furthermore, six out of ten women engaged in romantic relationships inside or outside the prison. Their need for intimacy and security is, for example, filled by a romantic relationship with a fellow inmate. Sexual relationships are a major taboo in Peruvian prisons, but still many detainees choose this form of intimacy. Though almost every Dutch prisoner denied being in a relationship with another woman, they pointed out that at least half of all the female prisoners started a relationship with one of their fellow inmates. 'At a certain point you just have a need for intimacy,' they said. As well as lesbian relationships, affinities between male and female detainees also occur. The women can write to men who are detained somewhere else in Peru or they meet each other while being transported to court. Shirley corresponds with several men. She giggles like a schoolgirl when a letter arrives. 'Well, you have to go on, on with your life, even if you're in prison,' she says.

Typical of prison life is the battle against time. Women in Peruvian prisons try to keep busy so that they 'won't go out of their minds'. The ways in which they try to keep busy differ. Some of them focus on taller, others join in sports tournaments that are organized in prison, but most remarkable is that some of the women mainly try to help others. Not every woman speaks Spanish, especially not the newcomers, so some 
women help others to fill out papers or translate important documents. Not only does this help their fellow inmates, it also enhances their self-esteem, which contributes to their struggle to survive their prison sentence. It is not a coincidence that some women use this coping strategy: they happen to be social workers outside the prison and so this coping strategy is a derivative from former life experiences. The circumstances in prison ensure that others actually need their help: for example, the lack of interpreters makes their help extremely necessary and welcome. Karin (36) claims to have helped many fellow inmates when she was still detained in Santa Monica prison: Everything happens for a reason, I think. I've helped tons of people inside, with papers, translations and so on. So maybe it was for a reason that I had to stay that long. For me it was also some sort of survival. I always worked in community serving jobs and for me it was a way to feel better. It made me feel better when I was still in prison. And it kept me busy.

A different survival strategy is to stop thinking. By refraining from thinking about the imprisonment and its consequences, the women try to cope with their incarceration. Jelena (24), for example stated: Just don't think, that's the secret. And don't have too much pity on yourself. The people I love, they're simply not here. But if I keep thinking about home and about my baby I won't make it. This is where I live now, and this is where I need to succeed. Some people are complaining all day: 'I can't do this anymore, I can't take it any longer.' And of course you're allowed to complain sometimes... but not all the time. 'Cos then I think fuck off, I have to do 14 years and you'll be out in just 2. But I keep smiling. If I feel depressed, I'll just stay in bed and afterwards I'll come downstairs like nothing happened. I always smile because otherwise I simply won't make it.

The circumstances in prison may also lead to the inability for women to be themselves, in order not to show any weaknesses. Some of the women in Peru put their true identities on hold, in order not to show any weaknesses. Eva (31), who was being treated for depression in the Netherlands prior to leaving for Peru, puts it like this: My depression is still there but I try to push it away. 'Cos if you show weakness in here, they will also treat you like that. So I think I just live on autopilot.

Furthermore, the length of the prison sentence influences the coping strategies of the female detainees we interviewed. Women who smuggled less than $10 \mathrm{~kg}$ of cocaine, were sentenced with 6.8 years in prison, with a chance on sentence reduction, in case of good behavior and joining taller. Women who smuggled over $10 \mathrm{~kg}$ of drugs, were sentenced with 15 years in prison, without a chance on reduced penalties. This last group of long-term prisoners deals with many of the same stressors as the women that 'only' got 6.8 years. But the women with shorter sentences are able to work towards a goal: sentence reduction. This gives the opportunity to use good behavior as a coping mechanism, to leave the Peruvian prison sooner. Women with a long-term sentence on the other hand, have little to gain from good behavior and taller, and many times withdraw themselves from both, fleeing for example into drug use.

\section{Conclusion}

In the research this article is based on, ethnographic research was carried out in two Peruvian prisons, and more specifically research was conducted on the ways in which 
Dutch women experience and survive a prison term far away from home after being arrested for drug trafficking.

In the first place, our research showed that the lives these women lived prior to their detention were often distressful. Furthermore, the circumstances they find in prison seem to influence the way they experience their imprisonment and the way they survive their prison term.

Prison life in Peru is very different from life in a Dutch prison and Dutch inmates in Peru are faced with all sorts of problems that are usually non-existent in their own country. The lack of privacy and the arbitrary regime in the Peruvian prison are tough on these women. According to the interviewees, health problems may originate and worsen due to a lack of hygiene and medical care. Furthermore, a language barrier often exists and most Dutch prisoners receive no visits from relatives. The circumstances in Peruvian prisons therefore seem to be tougher than circumstances in detention facilities in their home country. Because of that, the women in this small-scale study may experience harder deprivations than women in existing research on prison experiences.

Earlier research shows that prison conditions are of major influence on the wellbeing of prisoners [26,45,46]. Comparative research between prisons in California and The Netherlands, for instance, showed that female prisoners in The Netherlands were less depressed due to the relative humane circumstances in Dutch prisons [45]. "Where he or she sleeps, what and where he or she eats, whether he or she has a bed with sheets and blankets or sleeps on the floor, covered only with rags, all this has tremendous influence on his or her physical and mental well-being" ([45], 11). Comparative research between prisons in the United States, England and The Netherlands also showed that the particular nature of the prison regime, in the end explains the differences in the prisoners' psychological well-being, regardless of where they were imprisoned [46]. So we can imagine that serving time in Peru, is different than being imprisoned in "relatively humane Dutch prisons" ([26], 191), due to the differences in prison conditions. As no comparative research has been done between Peru and the Netherlands yet, no sure claims can be made. But as Kruttschnitt et al. [46] and Slotboom et al. [26] showed, the prison conditions determine the psychological wellbeing and the experienced amount of stress. We suggest that the amount of stress determines whether coping strategies are needed or not. It therefore seems plausible that the need of coping strategies is higher in Peruvian jails due to the amount of stress.

Though a need for coping strategies might be higher in Peru due to the stress caused by deprivations, it is carefully suggested that the ways in which our informants handle these deprivations do not differ from the coping strategies that were already found in prior prison research. Our respondents found support in religion and surrogate families, tried to help other inmates who are struggling, or simply tried to think as little as possible about their situation, similar to what earlier research by Clear et al. [25], Lazarus and Folkman [30], and Owen [10] showed. The coping strategies that the Dutch women used can possibly be traced back to the importation and deprivation theories discussed in the literature. The choice of a certain coping strategy seems to depend on prior life experiences and the circumstances in prison. With that, the coping strategies found in this small-scale ethnographic study seem to correspond with the general coping strategies described by Zamble \& Porporino [24].

A drawback in this study is the small number of respondents: it is therefore difficult to draw conclusions on this small-scale study. It would be fruitful to conduct more 
interviews with women who are imprisoned abroad to be able to further compare whether cultural background and prison conditions influence the experiences of incarcerated women.

We conclude to state that, though the imprisoned Dutch women lived tough lives and their stay in a foreign prison is hard, they manage, just like detainees who do time in their own countries, to cope and to survive.

Open Access This article is distributed under the terms of the Creative Commons Attribution 4.0 International License (http://creativecommons.org/licenses/by/4.0/), which permits unrestricted use, distribution, and reproduction in any medium, provided you give appropriate credit to the original author(s) and the source, provide a link to the Creative Commons license, and indicate if changes were made.

\section{References}

1. Anumba, N., Dematteo, D., \& Heilbrun, K. (2012). Social functioning, victimization, and mental health among female offenders. Criminal Justice and Behavior, 39(9), 1204-1218.

2. Chen, Y.-S., Lai, Y.-L., \& Lin, C.-Y. (2014). The impact of prison adjustment among women offenders: a Taiwanese perspective. The Prison Journal, 94(1), 7-29.

3. Jiang, S., \& Winfree, L. T., Jr. (2006). Social support, gender, and inmate adjustment to prison life: insights from a national sample. The Prison Journal, 86(1), 32-55.

4. Jones, R. S., \& Schmid, T. J. (2003). Parallels in the prison experiences of women and men. In B. H. Zaitzow \& J. Thomas (Eds.), Women in prison: gender and social control. Colorado: Lynne Rienner Publishers.

5. Kruttschnitt, C., \& Vuolo, M. (2007). The cultural context of women prisoners' mental health: a comparison of two prison systems. Punishment \& Society, 9(2), 115-150.

6. Slotboom, A. M., \& Bijleveld, C. (2007). Wat er in je hoofd en je hart zit weet niemand: gedetineerde vrouwen in Nederland. Justitiële verkenningen, 33(4), 72-88.

7. Steiner, B., \& Wooldredge, J. (2009). Individual and environmental effects on assaults and non-violent rule breaking by women in prison. Journal of Research in Crime and Delinquency, 46(4), 437-467.

8. Thompson, C., \& Loper, A. B. (2005). Adjustment patterns in incarcerated women: an analysis of differences based on sentence length. Criminal Justice and Behavior, 32(6), 714-732.

9. Warren, J. I., Hurt, S., Loper, A. B., \& Chauhan, P. (2004). Exploring prison adjustment among female inmates: issues of measurement and prediction. Criminal Justice and Behavior, 31(5), 624-645.

10. Owen, B. (1998). 'In the Mix'. Struggle and Survival in a Women's Prison. Albany: State University of New York Press.

11. Campbell, H. (2008). Female Drug Smugglers on the U.S.-Mexico Border: Gender, Crime, and Empowerment. Anthropological Quarterly, 81, 1, 233-267.

12. Reynolds, M. (2008). The war on drugs, prison building, and globalization: catalysts for the global incarceration of women. NWSA Journal, 20(2), 72-95.

13. PRISON (2005). PRISON overzicht mei 2005. Den Haag: MinBuZa.

14. PRISON (2010). PRISON overzicht januari 2010. Den Haag: MinBuZa.

15. Ministerie van Buitenlandse Zaken (2005). Gearresteerd in Peru. Den Haag: MinBuZa

16. Janssen, J. (1994). Latijnsamerikaanse drugskoeriersters in detentie: ezels of zondebokken? Arnhem: Gouda Quint.

17. Heffernan, E. (1972). Making it in prison: the square, the cool and the life. New York: Wiley.

18. Bailey, C. (2013). Exploring female motivations for drug smuggling on the island of Barbados evidence from Her Majesty's prison, Barbados. Feminist Criminology, 8(2), 117-141.

19. Islam-Zwart, K. A., \& Vik, P. W. (2004). Female adjustment to incarceration as influenced by sexual assault history. Criminal Justice and Behavior, 31(5), 521-541.

20. Green, B. L., Miranda, J., Daroowalla, A., \& Siddique, J. (2005). Trauma exposure, mental health functioning and program needs of women in jail. Crime and Delinquency, 51(1), 133-151.

21. Lynch, S., DeHart, D., Belknap, J., \& Green, B. (2012). Women's pathways to jail: The roles and intersections of serious mental illness \& trauma. Washington: US Department of Justice, Bureau of Justice Assistance.

22. Adams, K. (1992). Adjusting to prison life. Crime \& Justice: A Review of Research, 16(1), 275-359. 
23. Dhami, M. K., Ayton, P., \& Loewenstein, G. (2007). Adaption to imprisonment: indigenous or imported? Criminal Justice and Behavior, 34(8), 1085-1100.

24. Zamble, E., \& Porporino, F. J. (1988). Coping, behavior, and adaption in prison inmates. New York: Springer.

25. Clear, T.R., Hardyman, P.L., Stout, B., Lucken, K., Dammer, H.R. (2000). The value of religion in prison. An inmate perspective. Journal of contemporary criminal Justice, 16, 1, 53-74.

26. Slotboom, A. M., Kruttschnitt, C., Bijleveld, C., \& Menting, B. (2011). Psychological well-being of incarcerated women in the Netherlands: importation or deprivation? Punishment and Society, 13(2), 176197.

27. Liebling, A. (2004). Prisons and their moral performance. A study of values, quality and prison life. Oxford: Oxford University Press.

28. Lazarus, R. S. (1999). Stress and emotion: a new synthesis. New York: Springer Publishing Company.

29. Negy, C., Woods, D. J., \& Carlson, R. (1997). The relationship between female inmates' coping and adjustment in a minimum-security prison. Criminal Justice and Behavior, 24(2), 224-233.

30. Lazarus, R. S., \& Folkman, S. (1984). Stress, appraisal, and coping. New York: Springer.

31. Johnson, B. R., \& Larson, D. B. (1998). The faith factor. Corrections Today, 60(3), 106-110.

32. Aday, R. H., Krabill, J. J., \& Deaton-Owens, D. (2014). Religion in the lives of older women serving life in prison. Journal of Women \& Aging, 26(3), 238-256.

33. Scraton, P., \& Moore, L. (2005). Degradation, harm and survival in a women's prison. Social Policy \& Society, 5(1), 67-78.

34. Nuytiens, A. \& J. Christiaens (2010). Trajecten van vrouwelijke gedetineerden. Weinig jeugddelinquenten, veel late starters. Tijdschrift voor Criminologie, 52, 4, $394-410$.

35. Berger, P. L. (1963). Invitation to sociology a humanistic perspective. Garden City: Doubleday/Anchor Books.

36. Schmid, T. J., \& Jones, R. S. (1991). Suspended identity transformation in a maximum security prison. Symbolic Interaction, 14(4), 415-432.

37. Bryman, A. (2008). Social research methods. Oxford: Oxford University Press.

38. Jones, J. S., \& Watt, S. (2010). Ethnography in social science practice. Abingdon: Routledge.

39. Madden, R. (2010). Being ethnographic: A guide to the theory and practice of ethnography. London: Sage.

40. Arauco Padilla, M.B., Lujan del Carpio, M., Farfán Vargas, Y.R., Apolinario Ureta, C.A. \& Ugarte Arias, R.D. (2012). Informe Estadístico: Enero 2012. Retrieved on 7 August 2014 from http://www.inpe.gob.pe/ pdf/enero_2012.pdf

41. Soberon Garrido, R. (2011). Peru: drugs legislation and prison population in Peru. In P. Metaal \& C. Youngers (Eds.), Systems overload: drug laws and prisons in Latin America. Amsterdam: PrimaveraQuint.

42. Ministerio de Justicia \& Instituto Nacional Penitenciario (2008). Manual de derechos humanos aplicados a la funcion penitenciaria. Retrieved on 18 July 2013 from http:/www2.inpe.gob.pe/portal/archivos/ upload/trabajos/Manual_De_Derechos_Humanos.pdf

43. Miedema, F., \& Stoltz, S. (2008). Vast (gelopen) in den vreemde: een onderzoek naar het hoge aantal Nederlanders in buitenlandse detentie. Den Haag: WODC.

44. Van Tongeren, D. R., \& Klebe, K. J. (2010). Re-conceptualizing prison adjustment: a multidimensional approach exploring female offenders' adjustment to prison life. The Prison Journal, 90(1), 48-68.

45. Bhavnani, K. K., \& Davis, A. (1997). Fighting for her future: reflections on human rights and women's prisons in the Netherlands. Social Identities, 3(1), 7-33.

46. Kruttschnitt, C., Slotboom, A. M., Dirkzwager, A., \& Bijleveld, C. (2013). Bringing women's carceral experiences into the "new punitiveness" fray. Justice Quarterly, 30(1), 18-43.

47. Sykes, G. M. (1958). The pains of imprisonment. In G. M. Sykes (Ed.), The society of captives: A study of a maximum security prison. Princeton University Press: Princeton. 